\title{
Semantic-Communicative Structure and Word Order in Mandarin Chinese
}

\author{
Antoine Tremblay ${ }^{1}$, David Beck ${ }^{2}$ \\ ${ }^{1}$ Dalhousie University, Halifax, Canada \\ ${ }^{2}$ University of Alberta, Edmonton, Canada \\ Email: trea26@gmail.com
}

Received November $5^{\text {th }}, 2012$; revised December $4^{\text {th }}, 2012$; accepted December $11^{\text {th }}, 2012$

\begin{abstract}
In some languages more than in others, communicative considerations - such as what a message is about, what information is new or old, and whether this or that participant is in the Speaker's focus of attention - constrain the structure of a sentence. The goal of the present paper is to describe how different Semantic-Communicative Structures affect word order in simple mono-transitive sentences without coverbs or adverbial phrases in Mandarin Chinese. The discussion is couched in the Meaning-Text framework, relevant parts of which are clarified at the onset of the paper. We argue that Subject-Verb-Object (SVO) sentences are communicatively unmarked in that they do not signal any particular communicative consideration. Other word orders, however, specifically encode certain communicative considerations. This is the case of Prolepsis $\mathrm{i}_{\mathrm{i}}$-Subject $\mathrm{i}_{\mathrm{i}}$-Verb-Object $\left(\mathrm{P}_{\mathrm{i}} \mathrm{S}_{\mathrm{i}} \mathrm{VO}\right)$ and Object-Subject-Verb (OSV) sentences, which are discussed here.
\end{abstract}

Keywords: Semantic-Communicative Structure; Word Order; Mandarin Chinese; Meaning-Text Theory

\section{Introduction}

It has been argued by a number of linguists, among others, Chao (1968), Hu (1995), LaPolla (1988, 1993, 1995), Li and Thompson (1975, 1976, 1989), Li (2005), and Van Valin and LaPolla (1997), that word order in Mandarin Chinese (henceforth $\mathrm{MC}$ ) is determined to a great extent by informational/ communicative considerations (we will use the term "communicative" throughout this paper). In other words, a certain communicative structure will give rise to a certain order of constituents within the sentence. Li and Thompson (1976), among others, argue that the Topic-Comment communicative opposition is the determining factor affecting word order. $\mathrm{Li}$ and Thompson (1976: pp. 461-465) define the notion of Topic as a definite NP (i.e., one which the Addressee already knows and can identify) that specifies "the domain within which the predication holds" (i.e., it is the "centre of attention"). They maintain that Topics always occur in sentence-initial position ${ }^{1}$.

Although the sentence-initial element may be, and often is, definite and the centre of attention, in some instances it is neither. Consider the example in 1), where the interlinear glosses PFV and DE stand for perfective aspect and possessive respectively. Note that throughout the paper, the context in which examples are used is given between square brackets. Each context establishes a specific communicative structure and consequently constrains the set of sentences that can be used within it. Also note that the acceptability of each sentence in each context given in this paper was checked against linguistic intuition of nine native speakers of Mandarin Chinese. It is assumed our informants were able to extract the communicative structure

${ }^{1}$ Also see Lambrecht (1994: Chapter 4), and especially Section 4.7, pages 199-205, for a discussion of the "Topic-first principle". It is similar to LaPolla's (1995: 310) proposal, according to which topical elements occur in pre-verbal position while focal elements appear in post-verbal position. from the contexts and provide acceptability judgments accordingly.

1) $[\mathrm{A}$ 走进客厅, 看到许多糖果包装纸酒在四周. 她问 $\mathrm{B}$ 以下问题: “A comes into the living room and sees many candy wrappers lying all around. She asks B the following question"]:

$$
\begin{aligned}
& \text { A：谁吃了我的糖? } \\
& \text { [shei } \left.i_{\text {Comment }}\right] \quad[\text { chi le wo de tang }]_{\text {Topic }} \\
& \text { who eat PFV I DE candy } \\
& \text { "Who ate my candy?" } \\
& \text { B：张三吃了你的糖. } \\
& \text { [zhang.san }]_{\text {Comment }} \quad\left[\begin{array}{ccccc}
\text { chi } & \text { le } & \text { ni } & \text { de } & \text { tang }]_{\text {Topic }}
\end{array}\right. \\
& \text { Zhangsan eat PFV you DE candy }
\end{aligned}
$$

In 1), the Topic - expressed by the phrase consisting of the Verb 吃了 chi le "ate" and the definite NP 你的糖 ni de tang "your candy"- appears after the Comment, which is expressed by 张三 Zhangsan. Smith's (1991) test of Topichood, cited in Mel'čuk (2001: p. 105), can be used to demonstrate that 张三 Zhangsan is not a Topic. Smith's test can briefly be described as follows. A sentence can be paraphrased using the expression Speaking of $X, \cdots$ if $\mathrm{X}$ expresses the Topic of the sentence (or part of it). This is exemplified by the two following English sentences.

2) a) [Where $]_{\text {Comment }}$ is [the rabbit? $]_{\text {Topic }}$.

b) [The rabbit $]_{\text {Topic }}$ [is probably in Alice's garden $]_{\text {Comment. }}$.

c) Speaking of the rabbit ${ }_{i},\left[\mathrm{he}_{i}\right]_{\text {Topic }}[$ is probably hiding in Alice's garden $]_{\text {Comment }}$.

d) *Speaking of Alice's garden , [the rabbit $_{\text {Topic }}[$ is probably hiding there $\left.]_{j}\right]_{\text {Comment }}$.

(adapted from Mel'čuk, 2001: p. 105) 
The rabbit in $2 \mathrm{c}$ ) passes the test because it expresses the Topic, whereas Alice's garden in $2 \mathrm{~d}$ ) does not because it expresses the Comment. It is assumed here that in $\mathrm{MC}$, 说到 shuodao $\cdots$ is used in the same manner as English Speaking of -.. Turning back to our example in 1), it is shown in 3) that 张 三 Zhangsan is not a Topic.

$\begin{array}{ccc}\text { 3) a) } & \text { *说到 } & \text { 张三 } \\ & \text { shuo.dao } & \text { zhang.san } \\ & \text { speaking.of } & \text { zhang.san } \\ & & \\ \text { b) } & \text { 说到 } & \text { 你 } \\ & \text { shuo.dao } & n i \\ & \text { speaking.of } & \text { you }\end{array}$

他 吃
ta

"Speaking of Zhangsan, he ate your candy"

的
de

$\begin{array}{cccc}\text { 了 } & \text { 你 } & \text { 的 } & \text { 糖. } \\ l e & n i & \text { de } & \text { tang } \\ \text { PFV } & \text { you } & \text { DE } & \text { candy }\end{array}$

$\begin{array}{cc}\text { 吃 } & \text { 了 } \\ \text { chi } & \text { le } \\ \text { eat } & \mathrm{PFV}\end{array}$

"Speaking of your candy, Zhangsan ate them"

张三 Zhangsan in 3a) fails the test because it is a Comment, while the sentence in $3 \mathrm{~b}$ ) is grammatical given that 你的糖 $n i$ de tang "your candy" is part of the Topic, which, we wish to stress, occurs after sentence-initial 张三 Zhangsan.

In addition to being definite, the sentence-initial element can be indefinite, which runs counter to Li and Thompson's (1976) claim stated above. Consider the sentence shown in 4), where the interlinear gloss CL stands for classifier.

4) [一群人围成一堆在看什么东西, 张三看不到, 问其中 一个围观者发生什么事了, 这个人跟张三说: “People are gathering around something. Zhangsan cannot see and asks one of the bystanders what happened. The latter tells him the following"]:

$$
\begin{array}{ccccc}
\text { 一 } & \text { 个 } & \text { 工人 } & \text { 受伤 } & \text { 了 } \\
{[[y i} & g e & \text { gong.ren }]_{\text {Indefinite }} & \text { shou.shang } & l e]_{\text {Comment }} \\
\text { one } & \mathrm{CL} & \text { worker } & \text { injure } & \mathrm{PFV} \\
& \multicolumn{2}{c}{\text { "A worker was injured" }}
\end{array}
$$

The sentence in 4) is an all-Comment sentence. Neither 个工人 yi ge gong.ren "a worker" or 受伤了 shou.shang le "be injured" pass the 说到 shuo.dao $\cdots$ test (not shown here).

In this paper, we argue that word order in MC is determined - among other things - by a number of different communicative considerations, which are called Semantic-Communicative-oppositions within the Meaning-Text Theory (Žolkovskij \& Mel'čuk, 1967; Mel'čuk, 1988, 2001). It is important to stress the fact that Mel'čuk's (2001) perspective on communicative organization synthesizes, insofar as possible, the huge body of literature on the subject matter. As he mentions in the introduction to his book, he is in no way re-inventing the wheel. Rather, Mel'čuk integrated work done by many researchers spanning many decades to form what he argues to be a set of eight (semantic) communicative oppositions, which, depending on the language, affect the "translation" of meaning (semantic context) into text (a sentence).

In this study, our goal is to describe how different Semantic-Communicative Structures affect word order in simple mono-transitive sentences without coverbs or adverbial phrases ${ }^{2}$.

\footnotetext{
${ }^{2}$ Coverbs are defined in Po-Ching and Rimmington (2004) as verbs that are similar to English prepositions and that generally occur in conjunction with other verbs (e.g., dui "towards, facing", xiang "heading, towards", and zi "from").

${ }^{3}$ Word order in simple intransitive sentences has been discussed to some extent in Tremblay and Beck (2007). We relegate the analysis of di-transitive sentences and SOV sentences to future research.
}

We constrain our discussion to those Semantic-Communicative Structures that affect the initial position of a sentence ${ }^{3}$. In Section 2, we review relevant aspects of the Meaning-Text Theory. In Section 3, we discuss simple SVO, $\mathrm{P}_{\mathrm{i}} \mathrm{S}_{\mathrm{i}} \mathrm{VO}$, and OSV sentences. Finally, we give concluding remarks in Section 4.

\section{Meaning-Text Theory}

In this section we introduce relevant aspects of the Meaning-Text Theory (henceforth MTT; see Mel'cuk, 1988, 2001, for details). In the MTT framework, every utterance has a Semantic Structure (SemS), which encodes the propositional meaning of a sentence; this is the "objective" meaning of an utterance, which is structured as a connected oriented network of labeled nodes. A sample SemS is shown in Figure 1 (tense and number are not shown; single quotation marks are used to indicate the signified, that is, the semantics, of a linguistic sign).

In Figure 1, the numbers labeling the arcs differentiate the arguments of a functor (e.g., a verb, a preposition, etc.). That is, "John" is the $1^{\text {st }}$ argument of the functor "meet 1 " and "doctor" is its $2^{\text {nd }}$ argument, whereas "meet 1 " is the $1^{\text {st }}$ argument of the functor "place" and "airport" is its $2^{\text {nd }}$ argument. As the English sentences in 5) show, a single SemS can give rise to many surface syntactic forms.

5) a) John met the doctor at the airport [neutral prosody].

b) JOHN met the doctor at the airport [heavy stress on John].

c) It was John who met the doctor at the airport.

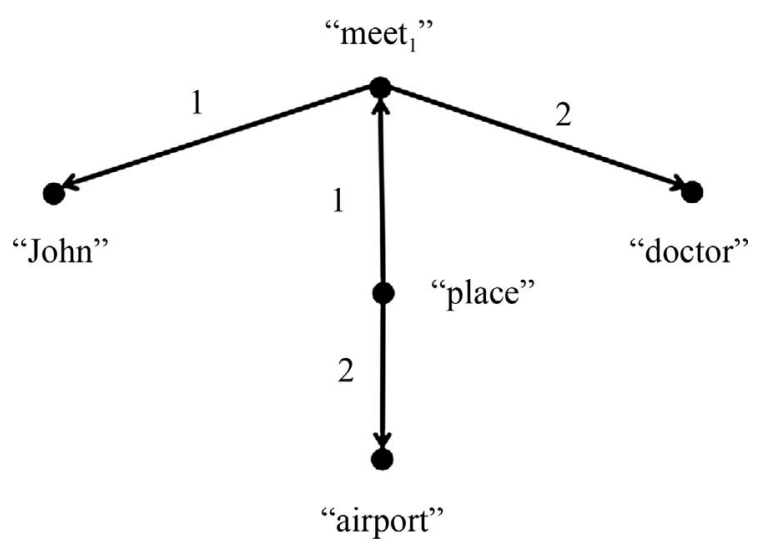

Figure 1.

A sample Semantic Structure (adapted from Mel’čuk, 2001: p. 5). 
The surface forms given in 5) depend on the SemanticCommunicative Structure (Sem-CommS) of each utterance, which specifies the manner in which the Speaker wishes to organize a message against the backdrop of a linguistic and/or extra-linguistic context (including world knowledge). Though the sentences in 5) all convey the same basic message, that is, that a man named John met a specific doctor at a specific airport, the Sem-CommS provides additional meaning, which is "superimposed" on top of the basic message. In 5a), the Speaker might simply be reporting on John's activities. In 5b), the Speaker may have vehemently wished to be the person assigned to meet a very famous doctor at the airport; instead another coworker named John, who couldn't care less about the doctor, was given the task (John is emotionally prominent for the Speaker). The sentence in $5 \mathrm{c}$ ) could be uttered in response to a statement, which the Speaker knows to be false, about Mary meeting the doctor at the airport (John would be, in this case, logically prominent).

In order to formally capture this "extra-layer of meaning", Mel'čuk formulated eight Semantic-Communicative oppositions by integrating, as much as possible, the colossal body of literature on communicative organization. These oppositions are: i) Thematicity (roughly the Topic-Comment dichotomy); ii) Givenness; iii) Focalization; iv) Perspective; v) Emphasis; vi) Presupposedness; vii) Unitariness; and viii) Locutionality. An example of a SemS with a partial Sem-CommS superimposed on it is given in Figure 2.

In Figure 2, "John" is the Rheme of the SemS, while "meet 1 ", "place", "airport", and "doctor" are part of the Theme. In addition, "John" is Focalized: He is presented by the Speaker as being logically prominent ( $\mathrm{s} / \mathrm{he}$ is communicating that it is precisely John and no one else).

The Sem-CommS determines the Deep-Syntactic Structure (DSyntS) of a sentence, which in turn determines its surface form. The partial DSyntS corresponding of the partial Semantic Representation (which is shown in Figure 2) is given in Figure 3. Note that small caps indicate lexemes, that is, the pairing of a signified to a signifier.

The arrows indicate Deep-Syntactic Relations (DSyntRels) such as the actantial DSyntRels I, II, the Attr(ibutive) DSyntRel, and the Coordinate DSyntRel (see Mel'čuk, 1988: pp. 63-67 for details). The dashed bi-directional arrow shows obligatory coreference between the two occurrences of the lexeme JOHN. In Figure 3, i) MEET $_{\text {Active }}$ has a DSyntRel I relation to IT-BE; ii) JOHN has a DSyntRel II relation to IT-BE as well as a DSyntRel I relation to MEET $_{\text {Active; }}$; iii) DOCTOR has a DSyntRel II relation to $\mathrm{MEET}_{\text {Active }}$; iv) AT $\longrightarrow$ AIRPORT has an Attributive relation to MEET $_{\text {Active; }}$ and v) AIRPORT has a DSyntRel II relation to AT (see Mel'cuk, 1988, for more information). In addition, the superimposed Deep-Syntactic-Communicative Structure indicates that vi) JOHN is the Rheme; vii) $\mathrm{MEET}_{\text {active, }}$, DOCTOR, AT, and AIRPORT are part of the Theme, and viii) JOHN is Focalized ${ }^{4}$.

Of the eight Sem-Comm oppositions, four are relevant to the present discussion namely, Thematicity, Givenness, Focalization, and Perspective; they are characterized in the following sections.

\footnotetext{
${ }^{4}$ The Deep-Syntactic-Communicative Structure specifies the division of the sentence into Theme-Rheme, Given-New, etc. Part of what constitutes the Sem-CommS is encoded, at this level, in the lexical choices made: For instance, choosing the frame IT-BE X WHO Y to indicate that X expresses a Focalized Rheme in English.
}

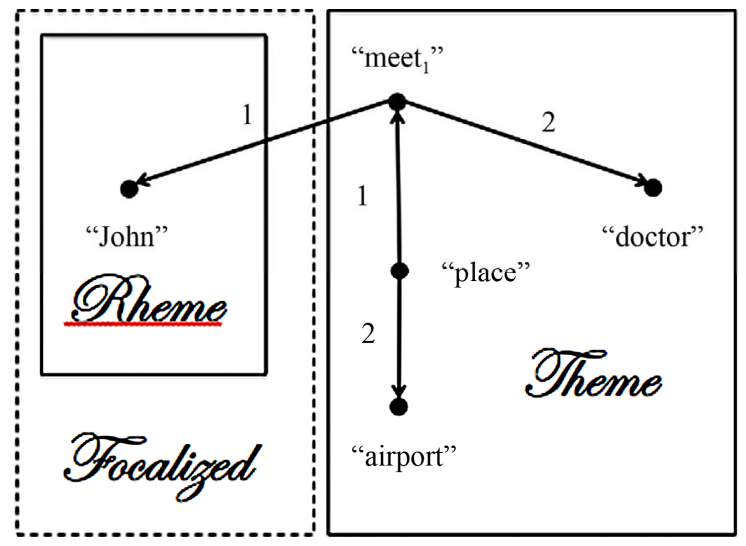

Figure 2.

The SemS + partial Sem-CommS of the sentence It is John who met the doctor at the airport.

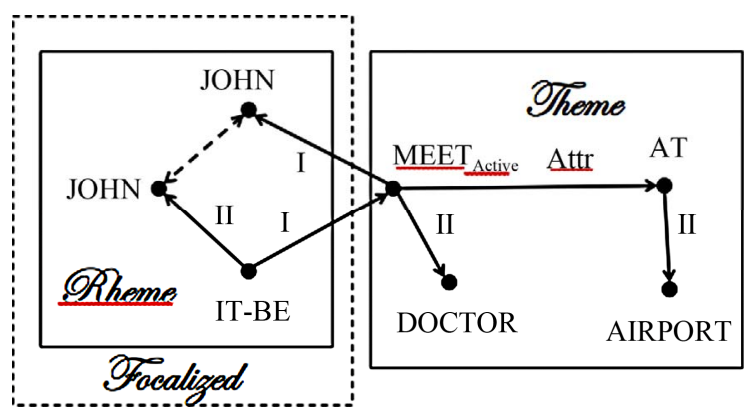

Figure 3.

A partial Deep-Syntactic Representation of Figure 2 (adapted from Mel'čuk, 2001: p. 9).

\section{Thematicity}

Thematicity has three values: Theme, Rheme, and Specifier, the last of which will not be considered here. The ThemeRheme opposition is the most universal and relevant in that a proposition necessarily says something (the Rheme) about something (the Theme). The Semantic Theme of a sentence can be defined as the part of its SemS that corresponds to what the message is about, and the Semantic Rheme as what is stated about the Theme by means of the sentence. By way of example, let us consider the short English dialogue shown in 6).

6) a) $[\text { What }]_{\text {Rheme }}[\text { did John catch? }]_{\text {Theme }}$.

b) $[\text { John caught }]_{\text {Theme }}[\text { a rabbit }]_{\text {Rheme }}$.

The configuration John caught expresses the Theme and a rabbit expresses the Rheme. That is, the event of John catching something is talked about and it is said about it that what was caught is a rabbit. Note that a sentence (i.e., a finite clause) necessarily has a Rheme. If no Rheme is present, the initial SemS gives rise to a nominal or infinitival phrase.

The notion of Theme is related to that of Topic, though the relation depends on how Topic is defined. For some, Theme and Topic are one and the same, while for others Theme is merely a portion of what constitutes a Topic. This will be discussed in more detail in Section 4.

\section{Givenness}

The Sem-Comm-opposition of Givenness is composed of three values: Given, New, and Not-Applicable. The value Given 
can be defined as the part of the SemS of a sentence that the Speaker presents as being in the Addressee's current consciousness or at least easily accessible for the Addressee. To say that something is in the Addressee's consciousness is to say that the Addressee can foresee it coming up next in the discourse and can uniquely identify its referent. This state of affairs can arise from i) linguistic context (e.g., preceding utterances) or ii) extra-linguistic context (e.g., world/encyclopedic knowledge shared by both the Speaker and the Addressee and/or from the situation in which the discourse takes place). The value New, on the other hand, characterizes words that are not in the Addressee's consciousness. That is, a New configuration is not accessible from either linguistic or extra-linguistic context nor can a pre-existing identity be found for its referent. Finally, Not-Applicable means that the Given-New division does not apply for a certain semantic configuration.

The Given-New opposition is an Addressee-oriented SemComm-opposition in that the Speaker chooses which part of the SemS is Given and which part is New according to what information he believes the Addressee can or cannot access. Some English examples are given below.

7) a) [The brothers had the quarrel over the book $]_{\text {Given }}$.

b) $[(\text { Some }) \text { brothers }]_{\mathrm{New}}$ [had the quarrel $]_{\text {Given }}$ [over the book $]_{\text {Given }}$.

c) $[\text { The brothers }]_{\text {Given }}[\text { had a quarrel }]_{\mathrm{New}}[\text { over the book }]_{\text {Given }}$.

d) $[\text { (Some) brothers had a quarrel over a book }]_{\mathrm{New}}$.

(adapted from Mel'čuk, 2001: pp. 161-162)

In 7a), the whole sentence is Given, that is, the Speaker believes that the Addressee can foresee what is coming up in the discourse and/or can assign unique identities to the referents. In $7 b$ ), however, the Speaker believes that the Addressee does not know "the brothers' identities"; this part of the sentence is therefore encoded as New. In 7c), the Addressee is believed to know nothing about the quarrel, which is coded as New. Finally in 7d), the Speaker thinks that the identity of the brothers, the quarrel, and the book are all unknown to the Addressee and the whole sentence is coded as New.

\section{Focalization}

Focalization has two values: Focalized and Non-Focalized. The former is defined as the part of a proposition that the Speaker presents as being logically prominent for him, that is, which is in the Speaker's focus of attention. A logically prominent configuration excludes any other possibilities. A NonFocalized element is simply not logically prominent (it is the unmarked value of the division). An example of Focalization in English was given in 5c), repeated here under 8).

8) [A is reporting on Mary's activities at a meeting. B knows John went to the airport to meet the doctor, not Mary].

A: $\cdots$ and Mary went to the airport to meet the doctor.

B: It was John who met the doctor at the airport.

In 8), John is logically prominent for B), who is telling A) and the people at the meeting that the person who met the doctor at the airport was precisely John, not anyone else.

Before moving on to the main portion of the paper, let us define the following two important concepts. The first one is the notion of "Prolepsis". The Prolepsis (P) is a sentential element that always occurs to the left of a sentence. It is syntactically very loosely connected to it and allows a pause to separate it from the rest of the sentence (Mel'čuk, 2001: p. 130). The second concept pertains to the "communicative markedness" of a word order. A communicatively unmarked word order is one that neutralizes different Sem-CommSs, that is, it can be used in sentences that express a number of different Sem-CommSs. ${ }^{5} \mathrm{~A}$ word order is marked with respect to another one if it en- codes fewer Sem-CommSs (potentially only one) than the word order it is compared to. By way of example, let there be word orders a) and b), and Semantic-Communicative Structures $\alpha$ and $\beta$ where i) the Subject in Sem-CommS $\alpha$ is Thematic, and ii) the Subject in Sem-CommS $\beta$ is Rhematic. Now, let us suppose that word order a) can encode Sem-CommSs $\alpha$ and $\beta$ whereas word order b) can only be used to encode Sem-CommS $\alpha$. Then word order b) is said to be marked relative to word order a). By way of example, let us consider the English SVO sentence in 9), where the Subject John expresses the Rheme.

9) a) $[\text { Who }]_{\text {Rheme }}[\text { met the doctor at the airport? }]_{\text {Theme }}$.

b) $[\text { John }]_{\text {Rheme }}[\text { met the doctor at the airport }]_{\text {Theme }}$.

The Subject in English SVO sentences can also express (part of) the Theme, as in 10).

10) a) $[\text { Who }]_{\text {Rheme }}[\text { did John meet at the airport? }]_{\text {Theme. }}$

b) $[\text { John met }]_{\text {Theme }}[\text { the doctor }]_{\text {Rheme }}[\text { at the airport }]_{\text {Theme }}$.

These two examples show that the Subject in English SVO sentences can be either Rhematic or Thematic. The Subject in Subject-clefted sentences, however, can only be Rhematic. Consider the short dialogue in 11), where A's answer is unacceptable.

11) [Two coworkers are talking about John, another coworker who is the boss' favorite employee. A famous doctor will be giving a presentation in the next few days and John asked to meet him at the airport. The two coworkers, who are big fans of the doctor's, know that John couldn't care less about him].

A: ' John was sent to the airport yesterday to meet someone. Do you know who?

B: No, who?

A: *It was $\left[[\text { John }]_{\text {Focalized }} \text { who met }\right]_{\text {Theme }}[\text { the doctor }]_{\text {Rheme }}[$ at the airport $]_{\text {Theme. }}$

B: Why didn't they send one of us two? They know we're huge fans of the doctor's!

In 11), John is a Theme because he is (part of) what the message is about; he is also Focalized because he and no one else went to the airport to meet the doctor. A's answer is unacceptable because in English Focalized Thematic Subjects are encoded by Pseudo-cleft sentences, as instantiated in 12), while Focalized Rhematic Subjects are encoded by Subject-cleft sentences, as shown in 13).

12) [The one whom John met at the airport $]_{\text {Theme,Focalized }}[$ was the doctor $]_{\text {Rheme. }}$

13) a) $[\text { Who }]_{\text {Rheme }}[\text { did John meet at the airport? }]_{\text {Theme. }}$

b) $[\text { John met }]_{\text {Theme }}[\text { Jack }]_{\text {Rheme }}[\text { at the airport }]_{\text {Theme }}$.

c) $[\text { It was the doctor }]_{\text {Rheme, Focalized }}[$ whom John met at the airport $]_{\text {Theme. }}$

Given that SVO sentences can encode Thematic and Rhematic Subjects whereas the (Focalized) Subject in Subjectclefted sentences can only be Rhematic, it can be said that SVO sentences in English are communicatively unmarked with respect to Subject-clefted sentences. We are now in a position to begin our discussion of word order in Mandarin Chinese.

\section{Simple Mono-transitive Sentences in Mandarin Chinese}

Word order in Mandarin Chinese, though flexible, is con-

\footnotetext{
${ }^{5}$ See Beck (2002: pp. 20-41) for a discussion of markedness.
} 
strained by Semantic-Communicative factors. In this section, we describe the Semantic-Communicative Structure of simple mono-transitive Subject-Verb-Object (SVO), Prolepsis $\mathrm{s}_{\mathrm{i}}$-Subject $\mathrm{i}_{\mathrm{i}}$-Verb-Object $\left(\mathrm{P}_{\mathrm{i}} \mathrm{S}_{\mathrm{i}} \mathrm{VO}\right)$, and Object-Subject-Verb (OSV) sentences. We argue that SVO sentences are communicatively unmarked, while the other two sentence types are marked. That is, whereas SVO sentences neutralize a number of SemCommSs, $\mathrm{P}_{\mathrm{i}} \mathrm{S}_{\mathrm{i}} \mathrm{VO}$ sentences encode Given Focalized Subjects, and OSV sentences specifically encode Focalized Objects. We will begin the discussion by demonstrating that the SemComm-opposition of Thematicity does not affect word order in mono-transitive sentences.

First consider the sentence in 14), where 小李 xiao li expresses the Rheme and 打破了花瓶 da po le huaping "broke the flower vase" the Theme.

\begin{tabular}{|c|c|c|c|c|}
\hline \multirow[t]{3}{*}{ 14) a) } & 谁 & 打破 & 了 & 花瓶？ \\
\hline & {$[\text { shei }]_{\text {Rheme }}$} & [da.po & le & hua.ping $]_{\mathrm{Them}}$ \\
\hline & who & hit.break & PFV & flower.vase \\
\hline
\end{tabular}

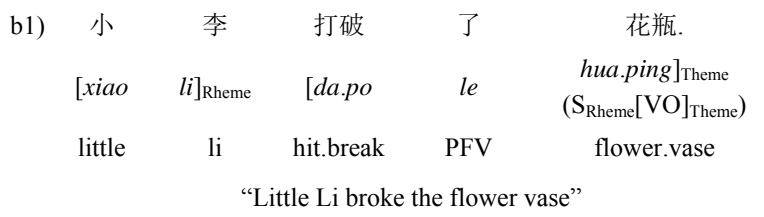

$$
\begin{aligned}
& \text { b2) 花瓶 小李打破了. } \\
& \begin{array}{cccc}
{[\text { hua.ping }]_{\text {Theme }}} & {[\text { xiao.li }]_{\text {Rheme }}} & \text { [da.po } & \begin{array}{c}
l e]_{\text {Theme }} \\
\text { flower.vase }
\end{array} \\
\text { little.Li } & \text { hit.break } & \text { PFV }
\end{array} \\
& \text { "The flower vase little Li broke" }
\end{aligned}
$$

In 14), either the Subject (expressing the Rheme) or the Direct Object (expressing part of the Theme) can appear in sentence-initial position. Now consider the following sentences, where the Semantic Subject 张三 Zhangsan, which is the element of the Semantic Representation expressed both as the

\begin{tabular}{|c|c|c|c|c|}
\hline \multirow[t]{4}{*}{ 15) a) } & 张三 & 打破 & 了 & 什么? \\
\hline & [zhang.san & [da.po & $l e]_{\text {Theme }}$ & {$[\text { shen.me }]_{\text {Rheme }}$} \\
\hline & zhang.san & hit.break & PFV & what \\
\hline & \multicolumn{4}{|c|}{ "What did Zhangsan break?" } \\
\hline \multirow[t]{6}{*}{ b) } & 张三 & 他 & 打破 & 了 \\
\hline & [zhang.san $_{i}$ & $t a_{i}$ & da.po & $l e]_{\text {Theme }}$ \\
\hline & zhang.san & he & hit.break & PFV \\
\hline & 你 & 的 & 花瓶. & \\
\hline & {$[n i$} & de & hua.ping $]_{\mathrm{Rheme}}$ & $\left([\mathrm{PSV}]_{\text {Theme }} \mathrm{O}_{\text {Rheme }}\right)$ \\
\hline & you & $\mathrm{DE}$ & flower.vase & \\
\hline
\end{tabular}
Prolepsis (P) and the Syntactic Subject (S) at the Deep-Syntactic Representation, can be a Theme 15) or a Rheme 16).

$$
\begin{aligned}
& \text { 16） a) 怎么 了? } \\
& \begin{array}{cc}
\text { [zen.me } & l e]_{\text {Rheme }} \\
\text { what happen } & \mathrm{PFV}
\end{array} \\
& \text { "What happened?" }
\end{aligned}
$$

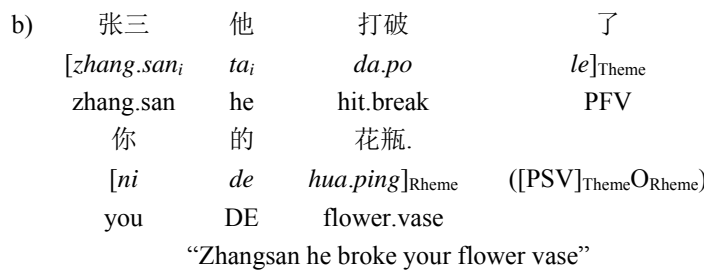

The Prolepsis Zhangsan in 15) and 16) occurs in sentenceinitial position because it is Given and Focalized (see below), not because it expresses the Theme or the Rheme. The data presented here clearly shows that Thematicity is not sufficient to describe word order in MC transitive sentences; other Semantic-Communicative oppositions are needed to account for the facts. In the following section, we discuss SVO sentences in more detail.

\section{SVO Sentences}

As was shown above, the Subject in SVO sentences can express either a Theme or a Rheme. In 19) and 20), it is shown that the Subject can also be Given or New, respectively.

17) [说到小王 “Talking about little Wang”]

$$
\begin{array}{ccccc}
\text { 他 } & \text { 编辑 } & \text { 这 } & \text { 本 } & \text { 杂志 } \\
{[t a]_{\text {Theme, Given }}} & \text { bian.ji } & \text { zhe } & \text { ben } & \text { za.zhi (S } \\
\text { he } & \text { edit } & \text { this } & \text { CL } & \text { magazine } \\
\multicolumn{4}{c}{} & \multicolumn{3}{c}{\text { "He edits this magazine" }} &
\end{array}
$$

18) [小王对老朱说: “Little Wang announces the following to old Zhu']:

$$
\begin{array}{clcccc}
\text { 有人 } & \text { 吃 } & \text { 了 } & \text { 你 } & \text { 的 } & \text { 盒饭. } \\
\text { [you.ren] }]_{\text {Rheme, New }} & c h i & l e & n i & \text { de } & \text { he.fan }\left(\mathrm{S}_{\text {Rheme, New }} \mathrm{VO}\right) \\
\text { someone } & \text { eat } & \text { PFV } & \text { you } & \text { DE } & \text { lunch.box } \\
& \text { "Someone ate your lunch box" } &
\end{array}
$$

In the following section, we discuss $\mathrm{P}_{\mathrm{i}} \mathrm{S}_{\mathrm{i}} \mathrm{VO}$ sentences.

\section{$\mathbf{P}_{\mathrm{i}} \mathrm{S}_{\mathrm{i}}$ VO Sentences}

As mentioned earlier, the Prolepsis $(\mathrm{P})$ is a sentential element that always occurs to the left of a sentence; it is syntactically very loosely connected to the rest of it and allows a pause separating it from the rest of the sentence (Mel'čuk, 2001: p. 130). When the Semantic Subject (in the Semantic Representation) is Given and Focalized (i.e., it is logically prominent), it is encoded in the Deep-Syntactic Representation both as a Prolepsis $(\mathrm{P})$ and a Subject $(\mathrm{S})$, giving rise to $\mathrm{P}_{\mathrm{i}} \mathrm{S}_{\mathrm{i}} \mathrm{VO}$ sentences. The examples shown in 19) and 20) demonstrate that the Semantic Subject in $\mathrm{P}_{\mathrm{i}} \mathrm{S}_{\mathrm{i}} \mathrm{VO}$ sentences is necessarily Given.

19) [战场上一个军营受到敌人的猛烈攻击, 士兵张三开 枪误伤了刘中尉. 战斗结束后, 朱战士对王战士说: “At war, a military camp sustained a heavy assault by the enemy. Zhangsan, a soldier, mistakenly shot lieutenant Liu. After the assault, soldier Zhu tells soldier Wang the following"]: 


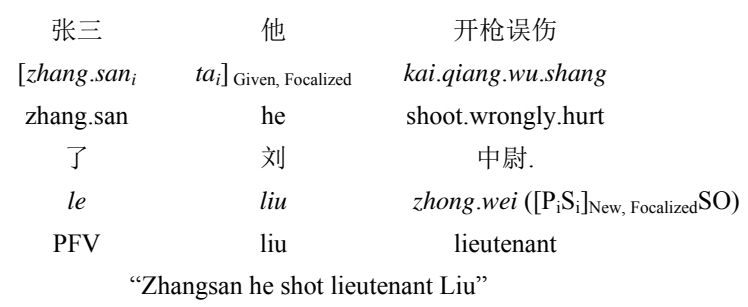

In 19), the Semantic Subject is Given and the sentence is acceptable (it was deemed acceptable by $77.8 \%$ (7/9) of the native speakers of Mandarin Chinese we asked for grammaticality judgments). The sentence in 20), however, is unacceptable because the Focalized Semantic Subject is New. Note that only $77.8 \%$ (7/9) native speakers of Mandarin Chinese deemed this sentence unacceptable in the given context (i.e., 22.2\% deemed it acceptable).

20) [战场上一个军营受到敌人的猛烈攻击, 一个士兵开 枪误伤了刘中尉. 战斗结束后, 中士向上校汇报了这个情况: "At war, a military camp sustained a heavy assault by the enemy. A soldier mistakenly shot lieutenant Liu. After the assault, the sergeant reported this to the colonel']:

$\begin{array}{ccccc}* \text { 一 } & \text { 个 } & \text { 士兵 } & \text { 他 } & \text { 开枪误伤 } \\ {[y i} & g e & \text { shi.bin }]_{\text {New, Focalized }} & t a_{i} & \text { kai.qiang.wu.shang } \\ \text { one } & \mathrm{CL} & \text { soldier } & \text { he } & \text { shoot.wrongly.hurt } \\ 了 & \text { 刘 } & \text { 中尉. } & & \left(\left[\mathrm{P}_{\mathrm{i}} \mathrm{S}_{\mathrm{i}}\right]_{\text {New, Focalized }} \mathrm{VO}\right) \\ l e & \text { liu } & \text { zhong.wei } & & \\ \text { PFV } & \text { liu } & \text { lieutenant } & \\ & & \text { "A soldier he shot lieutenant Liu” }\end{array}$

Given that $\mathrm{P}_{\mathrm{i}} \mathrm{S}_{\mathrm{i}} \mathrm{VO}$ sentences specifically encode Focalized Given Semantic Subjects, this sentence type is communicatively marked with respect to SVO sentences. We now turn to OSV sentences.

\section{OSV Sentences}

It is commonly believed that the Object in OSV sentences expresses the Theme of the sentence (Wei, 1989; Li et al., 1992; Mel'čuk, 2001; Paul, 2002). This is shown in 21).

21) [秘书看到自己的花瓶碎了. 她问小刘怎么回事儿. 小 刘说: “The secretary sees that her flower vase is broken. She asks little Liu what happened to it. Little Liu says the following"']:

$$
\begin{array}{cccccc}
\text { 你 } & \text { 的 } & \text { 花瓶 } & \text { 老板 } & \text { 打破 } & \text { 了 } \\
\text { [ni } & \text { de } & \text { hua.ping }]_{\text {Theme }} & \text { [lao.ban } & \text { da.po } & \begin{array}{c}
l e]_{\text {Rheme }} \\
\left(\mathrm{O}_{\text {Theme }} \mathrm{SV}\right)
\end{array} \\
\text { you } & \mathrm{DE} & \begin{array}{c}
\text { flower.vase } \\
\text { "Your vase, the boss broke" }
\end{array} & \text { bFV } & \text { hit.break }
\end{array}
$$

Although the Object in OSV sentences can be Thematic, it can also express the Rheme. This is illustrated in 22).

22) [李四问张三吃不吃鱼鯺, 张三说不吃. 李四问他吃不 吃鱼尾, 张三说也不吃, 然后说: “Lisi asks Zhangsan if he eats a fish's fins. Zhangsan says he doesn't. Lisi then asks him if he eats the tail. Zhangsan says he doesn't and then says"]:

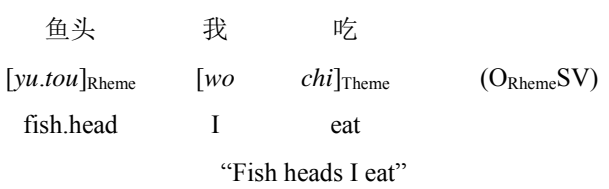

That 鱼头 yu.tou "fish heads" is a Rheme can be shown with the help of the 说到 shuo.dao "speaking of" for Thematicity in 23).

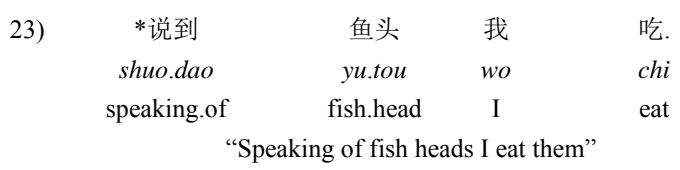

It is claimed here that Objects in OSV sentences occur in sentence-initial position not because they are what the message is about (i.e., Themes), but rather by virtue of being Focalized (i.e., logically prominent for the Speaker). In other words, 你 的花瓶 ni de hua.ping "your flower vase" in 21) occurs in sentence-initial position because the Speaker wishes to communicate that it is the flower vase that the boss broke and not something else, and in 22) 鱼头 yu.tou "fish heads" is the first element of the sentence because the Speaker eats precisely fish heads, not the fins or its tail.

The Object in OSV sentences cannot be New and Focalized in all-Rhematic sentences. This is illustrated in 24).

24) [老赵回家了. 他发现小周在哭. 老赵说: “Old Zhao comes back from work. He sees little Zhou crying and says the following"]:

$$
\begin{aligned}
& \text { 老赵: 怎么 了? } \\
& \text { old Zhao: zen.me le } \\
& \text { what.happen } \quad \mathrm{PFV} \\
& \text { "What happened?" }
\end{aligned}
$$

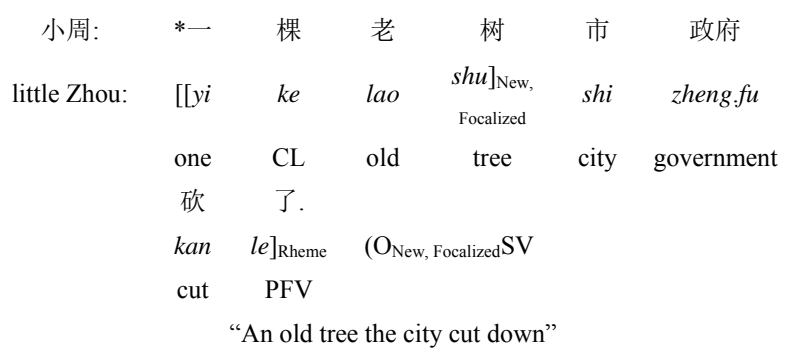

Rather, in such a situation a passive 被 bei constructions will be used and the Semantic Object (i.e., the $2^{\text {nd }}$ actant of the functor 砍 kan "cut" in the Semantic Representation) will be encoded at the Deep-Syntactic Representation as a Syntactic Subject; this is shown in 25).

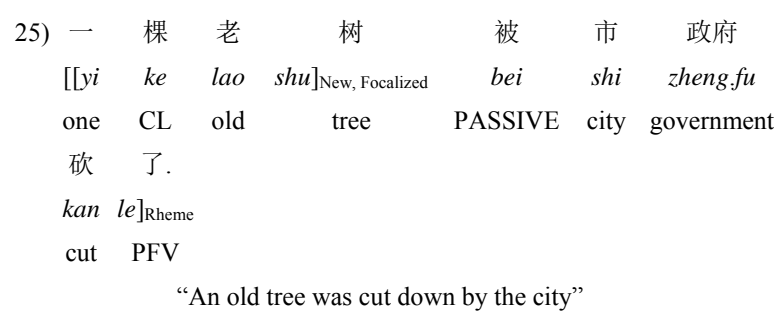


If the Object is Given and Focalized, as in 26), then an OSV sentence is acceptable.

26) [前院里有一棵小周特别喜欢的老树, 老赵回到家发 现小周在哭. 老赵说: “Little Zhou has an old tree in the front yard she loves a lot. Old Zhao comes back home from work. He sees little Zhou crying and asks"]:

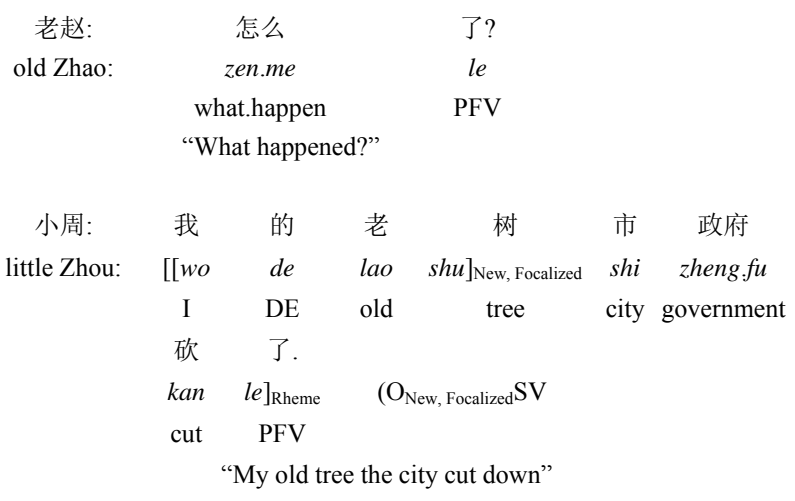

It can be shown that the Object in OSV sentences is Focalized but not in SVO sentences by using the construction 连... 都 “even” (where 连 lian means “even” and 都 dou means "all"). This construction has been said to indicate focus/emphasis/contrast (Zhang, 2000; Chen, 2004; Shyu, 2004; Wang, 2008) and is roughly taken to mean "in addition to $X$, and against expectations, also Y". Consider the sentences given in 27).

27) [John, 一个加拿大人, 和李四在一家餐馆吃饭. John 问李四他吃不吃鱼. 李四说他吃, 然后接着说: “At a restaurant, John, a Canadian, asks Lisi if he eats fish. Lisi says that she does and adds"]:

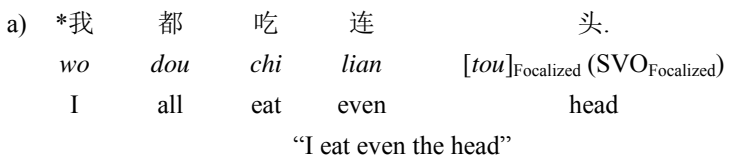

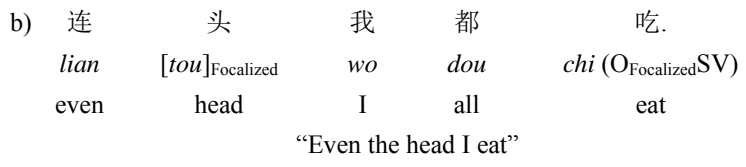

The sentence in 27a) is ungrammatical because Focalized Objects cannot appear in post-verbal position. The sentence in $27 \mathrm{~b}$ ), on the other hand, is acceptable given that the Focalized Object occurs in pre-verbal (sentence-initial) position where 连 …都 lian $\cdots$ dou highlights a contrast between the body of the fish and its head: John would expect Lisi to eat the flesh, but that Lisi also eats the head goes against his expectation (Wang, 2008, pp. 878-879).

Note that 连...都 lian ‥ dou “even” is not a Focalizer. As shown in 28), where the context is the same as in 27), the Object does not need 连... 都 lian ‥ dou “even" to be Focalized.

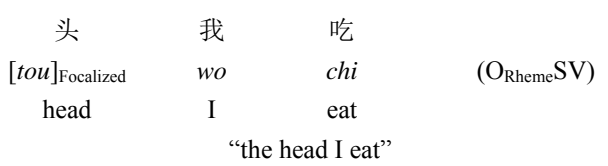

Given that OSV sentences specifically encode Focalized Objects and that they encode fewer Sem-CommSs than SVO sentences, the OSV sentences are communicatively marked.

\section{Conclusion}

The goal of the present paper was to describe how different Semantic-Communicative Structures affect word order in simple mono-transitive sentences without coverbs or adverbial phrases in Mandarin Chinese. We first demonstrated that the Theme-Rheme opposition is not sufficient to account for word order in MC, that is, the sentence-initial element in mono-transitive sentences can express the Theme or the Rheme. Subsequently, we showed that the Given-New opposition in concert with the Focalized-Not-Focalized dichotomy dictate whether a sentence exhibited the SVO, the $\mathrm{P}_{\mathrm{i}} \mathrm{S}_{\mathrm{i}} \mathrm{VO}$, or the OSV word order. Whereas the Subject in SVO sentences can be a Given Theme, a New Theme, a Given Rheme, or a New Rheme, the Subject in OSV sentences can be Given and Focalized or New and Focalized. In $\mathrm{P}_{\mathrm{i}} \mathrm{S}_{\mathrm{i}} \mathrm{VO}$ sentences, however, it has to be Given and Focalized.

Word order in Mandarin Chinese has been a topic of discussion in modern linguistics at least since the 1950's. Since then, a great number of studies have attempted to understand the underpinnings of word order in this language. Many researchers, including ourselves, agree that it is determined to a great extent by communicative consideration. To this date, theories of MC word order have relied on the Topic-Comment dichotomy. However, it remains unclear what a Topic is exactly. For Dik (1980), Topic is equivalent to the notion of Theme used in this paper. For Li and Thompson's (1976), the concept of Topic encompasses the Semantic-Communicative values of Theme, Given (which is equal at least in part to their definite), and in some cases Focalized. We hope to have convincingly demonstrated that it is preferable to dissociate these values in order to properly account for the different word orders in mono-transitive sentences in Mandarin Chinese.

\section{REFERENCES}

Beck, D. (2002). The typology of parts of speech systems: The markedness of adjectives. New York and London: Routledge.

Chao, Y.-R. (1968). A grammar of spoken Chinese. Berkeley and Los Angeles, CA: University of California Press.

Chen, C.-F. (2004). Asymmetrical behaviors of presuppositions of lianconstructions in Chinese. Unpublished Manuscript. https://webspace.utexas.edu/cfchen/NACCL16 chen2004.pdf

Dik, S. C. (1981). Functional grammar. Dordrecht and Cinnaminson: Foris.

Hu, W. (1995). Functional perspectives and Chinese word order. Ph.D. Dissertation, Columbus: Ohio State University.

Lambrecht, K. (1994). Information structure and sentence form: Topic, focus, and the mental representation of discourse referents. Cambridge: Cambridge University Press. doi:10.1017/CBO9780511620607

LaPolla, R. J. (1988). Topicalization and the question of lexical passives in Chinese. Third Annual Conference on Chinese Linguistics, 13-14 May 1988, Columbus: Ohio State University.

LaPolla, R. J. (1993). Arguments against "subject" and "direct object" as viable concepts in Chinese. Bulletin of the Institute of History and Philology, 63, 759-813.

LaPolla, R. J. (1995). Pragmatic relations and word order in Chinese. In P. Dowing, \& M. Noonan (Eds.), Word order in discourse (pp. 297-329). Amsterdam and Philadelphia: John Benjamins.

Li, C. N., \& Thompson, S. A. (1975). The semantic function of word 


\section{A. TREMBLAY, D. BECK}

order: A case study in Mandarin. In C. N. Li (Ed.), Word order and word order change (pp.163-195). Austin and London: University of Texas Press.

Li, C. N., \& Thompson, S. A. (1976). Subject and topic: A new typology of language. In C. N. Li (Ed.), Subject and topic (pp. 457-489). New York: Academic Press.

Li, C. N., \& Thompson, S. A. (1989). Mandarin Chinese: A functional reference grammar. London and New York: University of California Press.

Li, P., Bates, E., Liu, H., \& McWhinney, B. (1992). Cues as functional constraints on sentence processing in Chinese. In C. Hsuan-Chih, \& A. J. L. Tzeng (Eds.), Language processing in Chinese (pp. 207233). Amsterdam: North-Holland. doi:10.1016/S0166-4115(08)61893-2

$\mathrm{Li}, \mathrm{W}$. (2005). Topic chains in Chinese: A discourse analysis and applications in language teaching. Muenchen: Lincom Europa.

Mel'čuk, I. A. (1988). Dependency syntax: Theory and practice. New York: SUNY Press.

Mel'čuk, I. A. (2001). Communicative organization in natural language: The semantic-communicative structure of sentences. Amsterdam and Philadelphia: John Benjamins.

Po-Ching, Y., \& Rimmington, D. (2004). Chinese: A comprehensive grammar. New York and London: Routledge.

Shyu, S. I. (2004). (A)symetries between Mandarin Chinese lian...dou and shenzhi. Journal of Chinese Linguistics, 32, 81-128.

Smith, C. (1991). Sentences in text: A valediction for sentence topic. In C. Georgopolous, \& R. Ishihara (Eds.), Interdisciplinary approaches to language (Essays in Honour of S.-Y. Kuroda) (pp. 545-564). Dordrecht: Kluwer Academic Press. doi:10.1007/978-94-011-3818-5_29

Tremblay, A., \& Beck, D. (2007). Word order in Mandarin Chinese intransitive clauses. In K. Gerdes, T. Reuther, \& L. Wanner (Eds.), In Meaning-Text Theory 2007. Proceedings of the 3rd International Conference on Meaning-Text Theory (pp. 417-426). München and Wien: Wiener Slawistischer Almanach.

Van Valin Jr., R. D., \& LaPolla, R. J. (1997). Syntax. Structure, Meaning and Function. Cambridge: Cambridge University Press. doi:10.1017/CBO9781139166799

Wang, X. (2008). The semantics and pragmatics of lian ... dou/ye, lian, dou, and ye. In M. K. M. Chan, \& H. Kang (Eds.), Proceedings of the 20th North American Conference on Chinese Linguistics (NACCL20). Volume 2 (pp. 875-891). Columbus: The Ohio State University.

Wei, H. M. (1989). Word order of Mandarin Chinese. Ph.D. Dissertation. East Lansing, MI: Michigan State University.

Zhang, N. (2000). Object shift in Mandarin Chinese. Journal of Chinese Linguistics, 28, 201-246.

Žolkovskij, A., \& Mel'čuk, I. A. (1967). O semanticeskom sinteze [On semantic synthesis]. Problemy Kybernetiki, 19, 177-238. 